\title{
EFEKTIFITAS DIFFERENTIATED REINFORCEMENT OF INCOMPATIBLE BEHAVIOR (DRI) DALAM MENURUNKAN PERILAKU AGRESI VERBAL PADA REMAJA DENGAN MODERATE INTELLECTUAL DISABILITY
}

\author{
Lecya Lalitya dan Mayke S. Tedjasaputra \\ Fakultas Psikologi - Universitas Indonesia, \\ E-mail: lecyalalitya @gmail.com
}

Diserahkan 08 April 2019; Diterima 24 Juli 2019; Dipublikasikan 01 Agustus 2019

\begin{abstract}
ABSTRAK
Intellectutal disability (ID) adalah gangguan neurodevelopmental yang ditandai dengan keterbatasan dalam fungsi kecerdasan dan fungsi adaptif (konseptual, sosial, dan praktikal). Salah satu dampak dari keterbatasan kedua fungsi tersebut adalah masalah regulasi emosi, khususnya pada usia remaja. Dampaknya, anak lebih rentan pada masalah perilaku, seperti perilaku agresi verbal. Intervensi yang umum dilakukan untuk mengatasi masalah ini adalah intervensi ABA, salah satunya dengan metode differentiated reinforcement of incompatible behavior (DRI). Penelitian ini bertujuan untuk mengetahui efektifitas differentiated reinforcement of incompatible behavior (DRI) untuk menurunkan perilaku agresi verbal pada remaja dengan moderate intellectual disability. Penelitian dilakukan dengan desain single case A-B. Penelitian juga melibatkan teknik operant extinction dan reinforcement dalam intervensi. Hasil penelitian menunjukkan adanya penurunan perilaku agresi verbal pada remaja dengan moderate intellectual disability setelah menjalani intervensi perilaku dengan metode DRI. Partisipan juga lebih mampu meregulasi emosinya.
\end{abstract}

Kata Kunci: Differentiated reinforcement of incompatible behavior (DRI), agresi verbal, remaja, moderate intellectual disability

\section{EFFECTIVITY OF DIFFERENTIATED REINFORCEMENT OF INCOMPATIBLE BEHAVIOR (DRI) TO LOWER VERBAL AGGRESSION BEHAVIOR IN TEENAGER WITH MODERATE INTELLECTUAL DISABILITY}

\begin{abstract}
Intellectutal disability (ID) is a neurodevelopmental disorder characterized by limitations in intelligence functions and adaptive functions (conceptual, social, and practical). One of the effects of these limitations is problem with emotional regulation capability, especially in adolescence. As a result, children are more susceptible to behavioral problems, such as verbal aggression. A common intervention to overcome this problem is ABA intervention, one of which is the method is differentiated reinforcement of incompatible behavior (DRI). This study aims to determine the effectiveness of differentiated reinforcement of incompatible behavior (DRI) to reduce verbal aggression behavior in adolescent with moderate intellectual disability. The study was conducted with single-case A-B design. Research also involves operant extinction and reinforcement techniques in intervention. The results showed a decrease in verbal aggression behavior in adolescents with moderate intellectual disability after undergoing behavioral intervention with the DRI method. Participant also showed better emotional regulation strategy.
\end{abstract}

Key words: Differentiated reinforcement of incompatible behavior (DRI), verbal aggression behavior, adolescents, moderate intellectual disability 


\section{PENDAHULUAN}

Intellectutal disability (ID) adalah gangguan neurodevelopmental yang ditandai dengan keterbatasan dalam fungsi kecerdasan dan fungsi adaptif (konseptual, sosial, dan praktikal) (APA, 2013). Menurut APA (2013), individu dengan ID memiliki skor IQ di bawah 70 yang telah di konfirmasi melalui hasil tes inteligensi yang terstandarisasi. Keterbatasan ini berimplikasi pada kemampuan anak berpikir dan menyelesaikan dalam kehidupan sehari-hari. Di samping itu, keterbatasan dalam fungsi adaptif berkaitan dengan kemampuan konseptual, sosial, dan praktikal yang dipelajari untuk mampu berfungsi dalam kehidupan sehari-hari. Adanya keterbatasan pada kedua hal tersebut berdampak pada keberfungsian individu dalam kehidupannya.

Salah satu aspek yang tercangkup dalam fungsi adaptif adalah kemampuan seseorang untuk melakukan regulasi emosi. Emosi adalah keadaan psikologis yang merupakan hasil interaksi antara kognitif, ekspresi-motor, motivasi, dan komponen subjektif (Freitas-Magalhaes, dalam Pereira \& Faria, 2013). Selain itu, emosi juga dipengaruhi oleh perubahan dalam perkembangan motorik, bahasa, dan kognitif seseorang (Campos, Frankel and Camras, dalam Pereira \& Faria, 2013). Pada anak dengan keterbatasan kecerdasan (ID) regulasi emosi menjadi masalah yang sering muncul karena adanya keterlambatan dalam berbagai aspek yang menyebabakan perkembangan regulasi diri yang juga lebih lambat dari anak seusianya (Glenn \& Cunningham dalam Pereira \& Faria, 2013). Pada anak remaja ID, masalah regulasi emosi kemudian menjadi lebih sering muncul karena adanya gap antara perubahan hormon dan mood, dengan kemampuan penyesuaian dan regulasi diri (Marotz \& Allen, 2012; Pereira \& Faria, 2013).

Pada usia remaja anak melalui tahapan yang penting dalam perkembangan kognitif-emosi, sehigga menjadi tahapan dimana anak berlatih kemampuan menganalisa, memecahkan masalah, dan membagun pola regulasi emosi yang tepat (Peña \& Pacheco, 2012). Pada anak tipikal, kemampuan tersebut terus berkembang seiring bertambahnya usia, sehingga ia mampu menyesuaikan pola regulasi yang tepat sesuai dengan masalah yang di hadapi. Di sisi lain, hal ini sulit tercapai pada anak dengan ID karena adanya keterbatasan yang telah disebutkan sebelumnya. Dampaknya, terbentuk pola regulasi emosi yang tidak sesuai dan rentan pada berbagai masalah perilaku, seperti menyalahkan diri sendiri, selfharm, dan perilaku agresif (Totsika et al., dalam Wardany \& Choiri, 2017).

Salah satu masalah perilaku dan emosi yang ditunjukkan remaja ID adalah masalah perilaku agresif. Perilaku agresif didefinisikan sebagai segala bentuk perilaku yang bertujuan untuk menyakiti (Kassiove \& Sukhlodosky, dalam Elmasry, Fouad, Khalil, \& Sherra, 2016). Selanjutnya, Heilbron \& Prinstein (dalam Babore, Carlucci, Cataldi, Phares, \& Trumello, 2017), menyebutkan suatu perilaku dapat dikategorikan sebagai perilaku agresif apabila perilaku tersebut menyebabkan kerugian atau bahaya bagi orang lain dan diri sendiri. Kerugian yang disebabkan oleh perilaku agresif beragam mulai dari jangka pendek, seperti kerugian fisik, hingga kerugian jangka panjang, seperti trauma dan kesulitan diterima dalam lingkup sosial (Elmasry et al., 2016).

Secara umum, perilaku agresif dapat dibagi menjadi 3 ragam, yaitu perilaku agresi fisik, verbal, dan indirect (Elmasry et al., 2016). Perilaku agresi fisik dan verbal adalah perilaku agresif yang dapat diobservasi dan paling sering muncul pada anak dan remaja dalam berbagai situasi (rumah dan sekolah).

Agresi verbal didefinisikan sebagai perilaku menggunakan kata-kata agresif kepada orang lain (Hamilton, 2014). Ahsan (2015) menyebutkan, agresi verbal adalah perilaku menghina atau menyakiti yang dapat ditunjukkan dengan berteriak, berdebat, memaki, dan menggunakan kata sarkasme. Berdasarkan kedua definisi, agresi verbal adalah perilaku menghina dan menyakiti yang ditunjukkan dengan menggunakan kata agresif untuk berdebat dan memaki.

Perilaku agresif kemudian memberikan dampak pada berbagai aspek kehidupan, seperti dikucilkan dari lingkup sosial (Ahsan, 2015). Pada lingkup yang lebih besar, agresi verbal dapat mempengaruhi dan merugikan masyarakat secara kolektif karena dapat menyinggung kelompok tertentu dan memicu perselisihan antar kelompok masyarakat (Hamilton, 2014). Selain itu, sebagai bagian dari perilaku agresif, agresi verbal juga secara signifikan menjadi prediktor dari masalah penggunaan psikotropika (Matson, Dixon, \& Matson, 2005), masalah kriminal (Babore, et al., 2017), dan gangguan conduct (Fite, dalam Babore, et al., 2017). Di sisi lain, Menurut Kazdin (2013), perilaku perlu mendapatkan intervensi apabila dapat memunculkan masalah yang lebih besar di kemudian hari. Maka, perlu adanya intervensi yang tepat untuk menangani masalah perilaku agresi verbal pada remaja ID.

Kemunculan perilaku agresi verbal termasuk sebagai perilaku yang berlebihan (excessive behavior) (Martin \& Pear, 2015), sehingga intervensi yang diberikan bertujuan untuk mengurangi perilaku tersebut. Salah satu intervensi yang umum digunakan untuk masalah perilaku serupa adalah applied behavior analysis (ABA) (Chowdhury \& Benson, 2011). Intervensi ABA umumnya menggunakan aversive stimulus atau berupa punishment (hukuman), ketika perilaku tersebut tidak responsive pada prosedur yang lebih halus atau telah merugikan orang lain. Di sisi lain, metode ini menimbulkan kontroversi sehingga pemberi intervensi seharusnya terlebih dahulu menerapkan metode yang lebih halus. Metode yang dianggap lebih halus namun mampu menurunkan perilaku agresif adalah intervensi dengan metode differential reinforcement (Kazdin; Cowdery, Iwata, \& Pace, dalam Chowdhury \& Benson, 2011). Differential reinforcement adalah intervensi perilaku non-aversive yang terbukti efektif untuk menurunkan perilaku maladaptive (termasuk agresif) pada individu dengan ID. 
Chowdhury \& Benson (2011) merangkum penelitian-penelitian yang menggunakan intervensi perilaku dengan metode differential reinforcement, termasuk differential reinforcement of incompatible behavior (DRI). DRI adalah prosedur menurunkan atau menghilangkan perilaku yang tidak diinginkan dengan cara memperkuat incompatible behavior yang diinginkan (Martin \& Pear, 2015). Incompatible behavior adalah suatu perilaku yang hanya dapat muncul jika target perilaku tidak muncul. Sebagai contoh, apabila target perilakunya adalah agresi verbal yang ditunjukkan dengan menggunakan kata agresif pada orang lain, maka incompatible behavior-nya adalah menggunakan kata non-agresif (atau non-agresif). Hasil penelitian Chowdhury \& Benson (2011) menyebutkan bahwa DRI cukup jarang dilakukan dan dinilai kurang efektif jika tidak dikombinasikan dengan teknik lainnya. Sejalan dengan hal tersebut, Martin \& Pear (2015), menyebutkan bahwa DRI sangat efektif jika digabungkan dengan metode operant extinction dan positive reinforcement.

Operant extinction adalah penghilangan respon yang menjadi reinforcement (mempertahankan perilaku) atas target perilaku yang ingin dihilangkan atau dikurangi (Martin \& Pear, 2015). Hal ini berlandaskan pada anggapan bahwa target perilaku muncul dan bertahan karena diikuti dengan reinforcement, sehingga dengan menghilangkan reinforcement diharapkan dapat menghilangkan target perilaku karena tidak lagi mendapatkan reinforcement. Reinforcement kemudian diberikan pada perilaku lain (incompatible behavior) yang justru diharapkan muncul dan berlawanan dengan perilaku target. Hal ini diharapkan mampu mengurangi atau menghilangkan perilaku target karena tergantikan dengan kemucnulan incompatible behavior. Maka penelitian ini bertujuan mengetahui apakah penerapan DRI efektif menurunkan perilaku agresi verbal pada remaja dengan moderate intellectual disability. Penelitian ini juga mengkombinasikan DRI dengan teknik operant extinction dan positive reinforcement.

\section{METODE}

\section{Desain Penelitian}

Penelitian ini merupakan penelitian single case yang menggunakan desain $\mathrm{A}-\mathrm{B}(\mathrm{A}=$ baseline $-\mathrm{B}=$ treatment), yaitu membandingkan perilaku pada tahap baseline dan treatment untuk mengetahui apakah perilaku berubah sesuai dengan target yang telah ditentukan (Miltenberger, 2012). Menurut Kerlinger \& Lee, (2000), single subject design digunakan untuk mengevaluasi efektifitas intervensi pada suatu perilaku dengan membandingkan perilaku sebelum dan sesudah intervensi diberikan. Hal ini sesuai dengan tujuan penelitian, yakni mengetahui apakah penerapan intervensi modifikasi perilaku dengan teknik DRI efektif menurunkan perilaku agresi verbal pada remaja dengan moderate intellectual disability.

\section{Partisipan}

Partisipan penelitian adalah anak laki-laki berinisial $\mathrm{T}$ dan berusia 14 tahun. T memiliki gangguan moderate intellectual disability (IQ = 53, skala WISC). T dikeluhkan memiliki masalah regulasi emosi. T seringkali berbicara kasar kepada orang lain. Umumnya, perilaku tersebut muncul apabila keinginan $\mathrm{T}$ tidak dipenuhi atau kesal karena dijahili kakak, namun lebih sering dilontarkan kepada ibu dan nenek. Perilaku juga muncul dalam intensitas yang berbeda-beda, tergantung kondisi fisik dan pemicunya. Ada kalanya, perilaku muncul dengan intensitas rendah, yaitu $\mathrm{T}$ hanya mengucapkan kata kasar dengan volume normal. Di sisi lain, terkadang T mengucapkan kata kasar sembari berteriak-teriak ketika kondisi fisiknya sedang lelah dan menginginkan sesuatu. Dampak dari perilaku ini tidak hanya memberikan perasaan takut dan lelah, tetapi juga malu kepada tetangga. Teriakan yang dilakukan $\mathrm{T}$ dianggap sangat keras, dapat muncul kapan saja, dan sulit untuk diredakan tanpa dipenuhi keinginannya. Perilaku agresi verbal yang ia tunjukkan kemudian merugikan orang di sekitarnya dan menciptakan suasana tidak menyenangkan di rumah, seperti bertengkar dengan ibu, nenek, dan kakak. Menurut Kazdin (2013), sebuah perilaku perlu mendapatkan intervensi apabila telah menyebabkan bahaya dan menjadi sumber kekhawatiran bagi orang lain.

\section{Identifikasi Target Perilaku}

Perilaku agresi verbal adalah perilaku menghina dan menyakiti yang ditunjukkan dengan menggunakan kata agresif untuk berdebat dan memaki (Ahsan, 2015; Hamilton, 2014). Definisi operasional dari perilaku agresi verbal adalah perilaku menghina dan menyakiti yang ditunjukkan dengan menggunakan kata agresif untuk berdebat dan memaki orang lain. Pada penelitian dan program intervensi ini, yang termasuk dalam kata agresif adalah kata "anjing", "babi", bodoh, "bacot", "mampus" dan "ngentot".

\section{Prosedur Intervensi}

Prosedur intervensi diawali dengan melakukan functional behavioral assessment (FBA) untuk mengetahui dinamika anteseden, perilaku target intervensi, dan konsekuensi yang mempertahankan perilaku agresi verbal (Miltenberger, 2012).

Tabel 1. Hasil FBA

\begin{tabular}{lll}
\hline Antecedents $(\boldsymbol{A})$ & $\begin{array}{c}\text { Behaviors } \\
(\boldsymbol{B})\end{array}$ & $\begin{array}{c}\text { Consequences } \\
(\boldsymbol{C})\end{array}$ \\
\hline $\begin{array}{l}\text { Diganggu atau } \\
\text { dijahili orang }\end{array}$ & $\begin{array}{l}\text { Menunjukkan } \\
\text { perilaku }\end{array}$ & $\begin{array}{l}\text { Dinasehati oleh } \\
\text { keluarga }\end{array}$ \\
lain & agresi verbal & \\
Tidak & & Mendapatkan hal \\
mendapatkan hal & & yang diinginkan \\
yang diinginkan & & \\
\hline
\end{tabular}


Hasil FBA menunjukkan, perilaku agresi verbal yang ditunjukkan $\mathrm{T}$ muncul ketika ia diganggu atau dijahili oleh seseorang dan tidak mendapatkan hal yang ia inginkan. Saat perilaku agresi verbal muncul, ia kemudian dinasehati oleh keluarga (nenek, ibu, tante) atau justru mendapatkan hal yang ia inginkan. Hal tersebut kemudian mempertahankan perilaku agresi verbalnya.

\section{Baseline}

Pengambilan data baseline dilakukan untuk mengetahui frekuensi perilaku agresi verbal $\mathrm{T}$ sebelum mendapatkan intervensi modifikasi perilaku. Baseline dilakukan dengan meminta $\mathrm{T}$ untuk bermain bersama anggota keluarga (ibu) selama 30 menit. Peneliti kemudian mengobservasi dan melakukan perhitungan pada frekuensi kemunculan perilaku agresi verbal $\mathrm{T}$.

Pengukuran data baseline dilakukan dalam 3 hari. Setiap harinya dilakukan 2 sesi observasi, sehingga secara keseluruhan pengukuran baseline terdiri dari 6 sesi.

\section{Intervensi}

Berdasarkan hasil FBA dan baseline, intervensi akan berlangsung selama 8 hari yang terdiri dari 12 sesi. Setiap sesi diisi dengan kegiatan bermain selama 30 menit dan setiap hari dilakukan dua sesi intervensi. Peneliti akan melakukan evaluasi sesi pertama sebelum masuk ke dalam sesi kedua setiap harinya. Hal ini dilakukan karena mengingat keterbatasan kecerdasan $\mathrm{T}$, sehingga diperlukan pengulangan penjelasan, contoh, dan evaluasi untuk meningkatkan pemahamannya akan program intervensi.

Teknik utama yang digunakan dalam penelitian ini adalah differential reinforcement of incompatible behavior (DRI) adalah menurunkan/menghilangkan perilaku yang tidak diinginkan dengan cara memperkuat incompatible behavior yang diinginkan (Martin \& Pear,

Tabel 2. Ketentuan token economy

\begin{tabular}{|c|c|c|c|}
\hline $\begin{array}{l}\text { Sesi } \\
\text { Ke- }\end{array}$ & Ketentuan / target perilaku & Token & $\begin{array}{c}\text { Penukaran Backup } \\
\text { reinforcement }\end{array}$ \\
\hline 1 & Melakukan $1 \mathrm{x}$ incompatible behavior & 1 & \multirow{8}{*}{$\begin{array}{l}\text { Minimal } 10 \text { token } \\
\text { Pulsa Rp } 20.000\end{array}$} \\
\hline 2 & Melakukan $1 \mathrm{x}$ incompatible behavior & 1 & \\
\hline 3 & Melakukan $1 \mathrm{x}$ incompatible behavior & 1 & \\
\hline 4 & Melakukan $1 \mathrm{x}$ incompatible behavior & 1 & \\
\hline 5 & Melakukan $1 \mathrm{x}$ incompatible behavior & 1 & \\
\hline 6 & Melakukan $2 \mathrm{x}$ incompatible behavior & 1 & \\
\hline 7 & Melakukan $2 \mathrm{x}$ incompatible behavior & 1 & \\
\hline 8 & Melakukan $2 \mathrm{x}$ incompatible behavior & 1 & \\
\hline 9 & Melakukan 3x incompatible behavior & 1 & \multirow{8}{*}{$\begin{array}{l}\text { Minimal } 15 \text { token } \\
\text { Pulsa Rp } 100.00\end{array}$} \\
\hline 10 & Melakukan $3 \mathrm{x}$ incompatible behavior & 1 & \\
\hline 11 & Melakukan $3 \mathrm{x}$ incompatible behavior & 1 & \\
\hline 12 & Melakukan $4 \mathrm{x}$ incompatible behavior & 1 & \\
\hline 13 & Melakukan $4 \mathrm{x}$ incompatible behavior & 1 & \\
\hline 14 & Melakukan $4 \mathrm{x}$ incompatible behavior & 1 & \\
\hline 15 & Melakukan $4 \mathrm{x}$ incompatible behavior & 1 & \\
\hline 16 & Melakukan $4 \mathrm{x}$ incompatible behavior & 1 & \\
\hline
\end{tabular}


perilaku yang ia lakukan dan memahami tujuan program intervensi.

Selama sesi berlangsung, peneliti melakukan kegiatan bermain yang memiliki unsur persaingan dan menang-kalah, sehingga dapat memberikan peluang kemunculan perilaku agresi serta incompatible behavior. Permainan yang dipilih disesuaikan dengan kemampuan T, seperti kartu remi, ular tangga, kartu UNO (disederhanakan), membuat origami, dan permainan lomba pensil. Pada sesi ke-13dilakukan generalisasi yaitu melibatkan ibu dalam kegiatan bermain. Hal ini dilakukan agar perilaku agresi tidak hanya menurun saat bersama dengan peneliti, tetapi juga saat bersama ibu. Pada akhirnya, $\mathrm{T}$ diharapkan mampu menurunkan perilaku agresi verbal dalam natural setting.

\section{Post-test dan Follow up}

Tahap post test dilakukan sehari setelah intervensi selesai dilakukan. Post test dilakukan dalam waktu 2 hari yang terdiri dari 6 sesi pengambilan data. Hal ini dilakukan untuk mendapatkan data yang konsisten dan menggambarkan perubahan perilaku agresi verbal $\mathrm{T}$. Tahap follow Follow up dilakukan 2 minggu setelah seluruh sesi intervensi telah terlaksana. Hal ini dilakukan untuk mengetahui apakah perubahan yang dicapai selama program bertahan ketika program intervensi telah usai. Prosedur pada tahap post test dan follow up, dilakukan sama dengan tahap baseline, yaitu bermain bersama $\mathrm{T}$ dan anggota keluarga selama 30 menit.

\section{Pengumpulan Data}

Metode pengumpulan data yang dilakukan adalaha direct observation, yaitu mengambil data observasi secara langsung saat perilaku tersebut muncul (Miltenberger, 2012). Hal ini dilakukan peneliti dengan melakukan observasi perilaku agresi verbal $\mathrm{T}$ sembari melakukan suatu aktifitas (bermain) yang berlangsung selama 30 menit. Proses pencatatan menggunakan metode frequency, yaitu dengan menghitung frekuensi kemunculan perilaku dalam suatu rentang waktu (Milterberger, 2012).

\section{Analisa Data}

Menurut Gravetter \& Forzano (2012), penelitian yang menggunakan single case design tidak menggunakan teknik statistik untuk mengevaluasi hasil penelitiannya, melainkan dengan membandingkan perubahan hasil (grafik perilaku) antara sebelum (baseline/pre-test) dengan setelah (post test) mendapatkan intervensi. Proses tersebut disebut sebagai metode visual inspection, yaitu melihat perubahan pada data atau grafik.

Analisis data dilakukan dengan teknik analisis visual, yaitu analisis yang dilakukan untuk menentukan apakah terdapat hubungan atau pengaruh antara suatu variabel (perilaku agresi verbal) dengan variabel kedua (program intervensi perilaku) (Kratochwill et al., 2010). Fitur analisis visual yang digunakan adalah level dan trend. Level adalah nilai rata-rata data untuk setiap tahap pengambilan data. Pada penelitian ini, maka peneliti akan melihat rata-rata frekuensi perilaku agresi verbal tahap baseline, intervensi, dan post-test. Trend adalah garis lurus yang paling sesuai dengan pergerakan grafik data dan dapat memperlihatkan apakah data cenderung meningkat, menurun, atau tidak ada perubahan. Pada penelitian ini, trend dapat dilihat pada tabel-tabel grafik data setiap tahapan pengambilan data.

Kratochwil et al. (2010) menyebutkan, terdapat empat tahap dalam melakukan analisis visual, yaitu (1) mendokumentasikan pola data pada tahap baseline, (2) meninjau data pada setiap tahap pengambilan data (sebelum dan setelah manipulasi intervensi diberikan), (3) melakukan analisis visual dengan membandingkan data pada setiap tahapan pengambilan data untuk menentukan hubungan atau pengaruh antar kedua variabel, dan (4) menggabungkan seluruh data untuk menarik kesimpulan. Keempat tahapan tersebut akan dilakukan pada penelitian ini untuk menentukan apakah penerapan penerapan intervensi modifikasi perilaku dengan teknik DRI efektif menurunkan perilaku agresi verbal pada remaja dengan moderate intellectual disability.

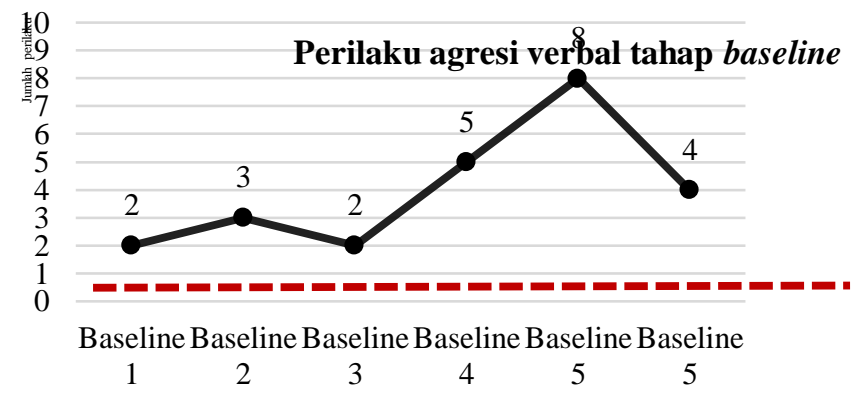

-Perilaku agresi verbal

Gambar 1. Perilaku

Perilaku agresi verbal

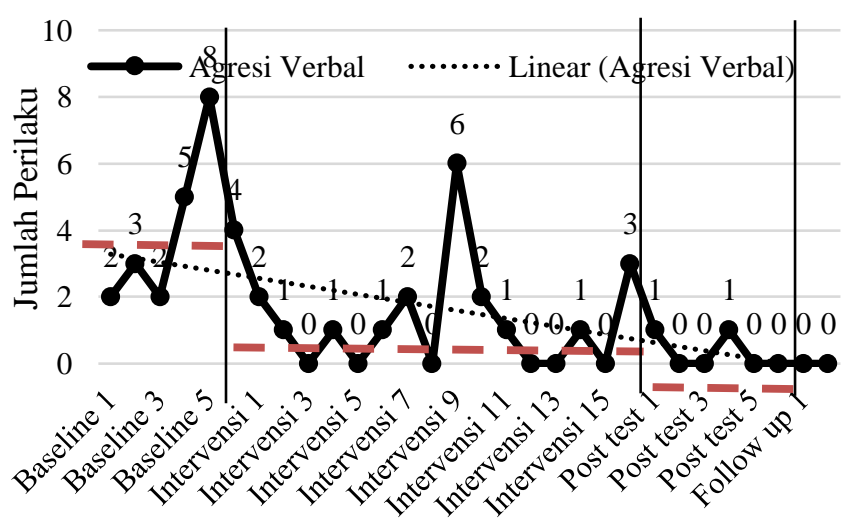

Gambar 2. Perbandingan 


\section{HASIL DAN PEMBAHASAN}

\section{Tahap Baseline}

Pengambilan data baseline dilakukan melalui metode observasi waktu 3 hari dan setiap hari dilakukan 2 aktifitas yang berbeda, sehingga setiap hari dilakukan dua sesi observasi baseline. Observasi baseline dilakukan saat $\mathrm{T}$ bermain kartu bersama peneliti, tante, dan ibu.

Berdasarkan gambar 1, T rata-rata menunjukkan 4 kali perilaku agresi verbal dalam 30 menit (garis putusputus pada gambar 2), dengan frekuensi tertinggi adalah 4 kali. Perilaku tersebut ditunjukkan $\mathrm{T}$ terhadap ibu dan peneliti ketika ia mengalami kekalahan saat bermain, serta keinginannya tidak dipenuhi oleh tante. Kata agresif yang disebutkan T antara lain "anjing", "babi", bodoh, "bacot", "mampus" dan "ngentot". Ketika menunjukkan perilaku agresi verbal, ibu menasehati $\mathrm{T}$, tetapi tidak memberikan konsekuensi lebih lanjut, dan kembali melanjutkan kegiatan. Di sisi lain, tante T bersikap lebih tegas yang ditunjukkan dari nada berbicaranya kepada $\mathrm{T}$, sehingga $\mathrm{T}$ mengucapkan "maaf" pada tante.

\section{Tahap Intervensi, Post test, dan Follow up}

\section{Frekuensi penggunaan kata agresif dan non-agresif}

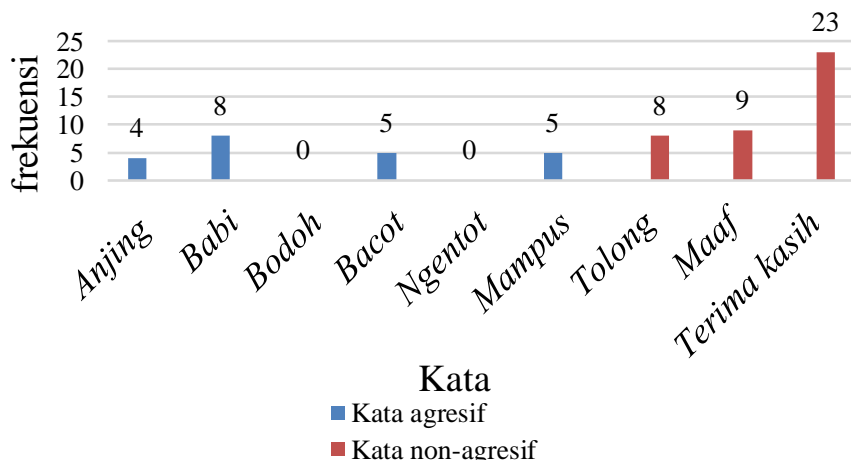

Gambar 3. Frekuensi penggunaan kata agresif dan non-agresif

Hasil analisis menunjukkan level dan garis trend yang menurun pada perilaku agresi verbal $\mathrm{T}$ setelah mendapatkan intervensi modifikasi perilaku dengan penerapan teknik differentiated reinforcement of incompatible behavior (DRI). Hal ini sejalan dengan hasil penelitian sebelumnya yang juga menunjukkan bahwa teknik DRI efektif menurunkan perilaku agresif (Spira, Koven, \& Edelstein, 2004; Chowdhury \& Benson, 2011; Wardany \& Choiri, 2017). Berdasarkan Wardany \& Choiri (2017), teknik DRI efektif untuk menurunkan perilaku agresif pada anak dengan ID di kelas karena adanya reinforcement yang berfungsi sebagai penguat kemunculan incompatible behavior. Hal serupa terjadi pada penelitian ini, yakni $\mathrm{T}$ mendapatkan token sebagai reinforcement pada kemunculan incompatible behavior. Dengan demikian, ia memahami perilaku yang diharapkan dan dihargai oleh lingkungannya, sehingga menurunkan perilaku agresi verbal (perilaku yang tidak diharapkan).
Pada gambar 2 terlihat adanya penurunan level atau rata-rata perilaku agresi verbal yang ditunjukkan T. Pada tahap baseline, rata-rata $\mathrm{T}$ menunjukkan perilaku agresi verbal sebanyak 4 kali dalam kurun waktu 30 menit, yang kemudian menurun menjadi 1 kali pada tahap intervensi.

Frekuensi perilaku agresi verbal tertinggi selama tahap intervensi yang ditunjukkan $\mathrm{T}$ adalah sebanyak 6 kali pada sesi ke-9 yaitu saat bermain adu jauh melempar origami pesawat. Hal yang membedakan permainan ini dengan permainan lainnya dan dapat menyebabkan tingginya frekuensi perilaku agresi adalah keterlibatan aktifitas fisik sederhana, yakni harus mengambil pesawat yang terbang cukup jauh di taman. Perbedaan ini dapat meningkatkan kemunculan perilaku agresi verbal karena dapat berkaitan dengan kondisi fisik $\mathrm{T}$ yang lelah sepulang sekolah. Pada sesi tersebut, rasa lelah setelah pulang sekolah, kesal karena kalah, dan aktifitas fisik yang lebih banyak dari biasanya meningkatkan perilaku agresi verbal $\mathrm{T}$.

Di sisi lain, terdapat pula sesi dimana $\mathrm{T}$ sama sekali tidak menunjukkan perilaku agresi vebal (frekuensi 0). Level frekuensi perilaku agresi verbal kemudian kembali mengalami penurunan menjadi 0.33 (dibulatkan menjadi 0) pada tahap post test dan bertahan hinga tahap follow up. Pada tahap post test, T hanya menunjukkan 2 kali perilaku agresi verbal selama 6 kali sesi pengambilan data sementara pada sesi lainnya ia tidak menunjukkan perilaku agresi verbal sama sekali. Berdasrkan hal tersebut, penurunan frekuensi perlaku agresi verbal $\mathrm{T}$ memenuhi target program intervensi, yaitu menurun dan atau hilang sama sekali (frekuensi 0).

Sejalan dengan menurunnya level perilaku verbal, gambar 2 juga menunjukkan pergerakan turun pada trendline sepanjang grafik frekuensi perilaku agresi

verbal. Hal ini menunjukkan, terjadi penurunan perilaku agresi verbal yang ditunjukkan $\mathrm{T}$ dari tahap baseline hingga tahap intervensi, post test, dan bertahan hingga follow up. Berdasarkan hal tersebut, maka penerapan DRI mampu menurunkan perilaku agresi verbal pada remaja dengan moderate intellectual disability.

Peneliti melakukan pengukuran frekuensi atau ragam kata agresif dan kata non-agresif yang ditunjukkan $\mathrm{T}$ (gambar 3). Diketahui bahwa kata agresif yang paling sering digunakan $\mathrm{T}$ adalah kata "babi" dengan frekuensi kemunculan sebanyak 8 kali selama 16 sesi intervensi dan 6 sesi post test. Kemudian, frekuensi tertinggi diikuti dengan kata "bacot" (5 kali), "mampus" (5 kali), "anjing" (4 kali), dan" bodoh" (2 kali). Di sisi lain, kata "ngentot" tidak pernah ia gunakan dalam 16 kali sesi intervensi dan 6 sesi post test.

Gambar 3 juga menunjukkan frekuensi kata nonagresif yang paling sering digunakan, yaitu kata "terima kasih" (23 kali) selama 16 sesi intervensi. Selanjutnya, frekuensi tertinggi kedua adalah kata "maaf" (9 kali) dan ketiga adalah kata "tolong" (8 kali).

Peneliti juga melakukan observasi pada perilaku 
dan interaksi T dengan anggota keluarga, serta wawancara dilakukan kepada $\mathrm{T}$, ibu, dan tante $\mathrm{T}$. Hasil yang ditemukan adalah pertama, berkaitan dengan frekuensi penggunaan kata agresif (gambar 3), penggunaan kata agresif yang paling sering adalah kata "babi". Berdasarkan observasi, $\mathrm{T}$ menggunakan kata tersebut ketika ia kalah dalam permainan. Ia tidak secara langsung memaki peneliti ataupun mengarahkan ejekan "babi" pada seseorang, melainkan sebagai ekspresi kekesalan. Hal serupa juga berlaku untuk kata "anjing". Di sisi lain, ketika menggunakan kata "mampus", $\mathrm{T}$ spesifik mengucapkannya pada lawan bermain, seperti peneliti atau ibu ketika $\mathrm{T}$ berhasil mengalahkan lawan bermain. Kata "bacot" $\mathrm{T}$ gunakan saat berbicara kepada ibu, terutama ketika ibu menasehati T. Hal tersebut menunjukkan seolah $\mathrm{T}$ tidak peduli dengan perkataan ibu.

Kedua, berkaitan dengan frekuensi penggunaan kata non-agresif (gambar 3) yang paling tinggi adalah kata "terima kasih". T umumnya mengucapkan "terima kasih" setelah peneliti membagikan kartu, mengajarinya cara melipat origami, atau memberikan benda terkait permainan kepadanya. Selanjutnya, kata "maaf" T ucapkan ketika peneliti menegurnya berbuat curang dalam permainan, mengucapkan kata agresif, dan saat melakukan evaluasi bersama ibu. Akan tetapi, T terlihat sulit mengatakan kata "maaf" pada ibu apabila ia melakukan kesalahan, sehingga peneliti masih perlu memberikan prompt verbal. $\mathrm{T}$ juga cenderung hanya mengucapkan kata non-agresif saja, namun tidak sepesifik atau tidak mengucapkannya dalam kalimat. Contohnya, ia mengucapkan "tolong" sembari memberikan tumpukan kartu pada peneliti, tanpa mengucapkan "kak tolong dikocok kartunya". Peneliti kemudian mendorong T untuk mengucapkannya dalam kalimat lengkap.

Ketiga, T memiliki pemahaman yang lebih baik akan dampak perilaku agresi verbal serta penggunaan kata non-agresif ("maaf", "tolong", dan "terima kasih") yang tepat. $\mathrm{T}$ awalnya tidak memahami perilaku yang berlawanan (incompatible) dari perilaku agresi verbal (menggunakan kata agresif), sehingga peneliti memberikan penjelasan kata non-agresif, serta kapan kata tersebut tepat digunakan. Dalam pelaksanaan sesi 1 hingga 4, T masih terlihat bingung kapan kata tersebut sebaiknya digunakan, sehingga peneliti perlu memberikan prompt verbal yang cukup banyak. Contoh prompt yang diberikan adalah peneliti mengatakan “...bilang apa kalo mau dibantu kocok kartu" ketika T kesulitan mengocok kartu permainan. Peneliti berupaya memberikan contoh konkrit dan melakukan latihan penggunaan kata nonagresif tersebut bersama T. Hal ini kemudian menjadi faktor yang mendukung keberhasilan intervensi karena berkaitan dengan karakteristik $\mathrm{T}$ yang memiliki fungsi kecerdasan di bawah rata-rata anak seusianya (IQ $=53$, skala WISC). Menurut Algahtani (2017), anak dengan keterbatasan fungsi kecerdasan memerlukan penjelasan sederhana, contoh, serta pengulangan materi belajar agar mampu memiliki pemahaman yang baik. Penjelasan yang diberikan peneliti kemudian mampu memberikan pemahaman yang leih baik kepada T mengenai mengapa perilaku agresi verbal seharusnya tidak dilakukan dan pentingnya penggunaan kata non-agresif. Seiring berjalannya waktu, perilaku muncul tanpa perlu diberikan prompt. Selain itu, menurut ibu $\mathrm{T}$ juga berusaha menyampaikan pengetahuan mengenai kata agresif dan kata non-agresif kepada kakak yang juga seringkali menunjukkan perilaku agresi verbal.

Keempat, $\mathrm{T}$ menunjukkan regulasi emosi yang lebih baik selama sesi intervensi berlangsung. Pada tahap baseline dan sebelum intervensi dilakukan, $\mathrm{T}$ umumnya langsung menunjukkan agresi verbal yang terkadang diikuti dengan perilaku agresif lainnya (memukul) ketika merasa marah. Akan tetapi, saat sesi berlangsung, T meregulasi emosinya dengan memperkuat kepalan tangannya dan mengalihkan pandangan dari hal yang membuatnya marah.

Lotfali, Moradi, \& Ekhtiari (2016) menyebutkan bahwa keadaan marah seorang individu dapat terlihat melalui postur tubuhnya, yakni tangan yang mengepal dan pola pernafasan yang cepat. Di sisi lain, individu dengan keadaan rileks menunjukkan postur yang rileks pula dan pola pernafasan yang lebih lambat, menarik nafas dengan hidung, dan membuang nafas melalui mulut. Pola pernafasan tersebut umumnya disebut sebagai teknik deep breathing. Guna membantu $\mathrm{T}$ meregulasi emosinya, peneliti mengajarkan teknik deep breathing sebanyak satu kali (sesi kedelapan). Peneliti meminta T melakukan deep breathing sebanyak 4 siklus ( 1 siklus $=5$ tarikan $\& 5$ hembusan nafas). Pada sesi selanjutnya, T kemudian melatih metode relaksasi yang diajarkan peneliti hingga kemudian kepalan tangannya melemah dan menunjukkan redamnya luapan emosi yang ia rasakan. Selain itu, saat terlihat ingin menggunakan kata agresif, $\mathrm{T}$ cenderung menutup mulut dan mengalihkan pandangannya. Hal tersebut menunjukkan T memiliki kontrol yang lebih baik atas caranya mengelola emosi. Hal tersebut juga sejalan dengan penelitian oleh Lotfali et al., (2016), yang menunjukkan bahwa pelatihan regulasi emosi (deep breathing) mampu menurunkan emosi marah pada remaja, yang juga berkaitan dengan penurunan perilaku agresif.

Adanya pemberian teknik deep breathing pada penelitian ini merupakan penyesuaian program intervensi yang disesuaikan dengan kebutuhan klien. Hal ini merupakan salah satu kelebihan dari penelitian dengan desain single case (Gravetter \& Forzano, 2012), yakni penyesuaian program intervensi sesuai kebutuhan dan karakteristik partisipan yang kemudian hasilnya dapat bermanfaat dalam situasi psikologi klinis. Namun, tindakan ini dapat menjadi mediating factor yang berkontribusi pada hasil penelitian, sehingga perlu diperhatikan bahwa terdapat faktor yang menjembatani antara teknik DRI dan penurunan perilaku agresi verbal. Maka, disarankan pada penelitian selanjutnya untuk mengkombinasikan teknik intervensi perilaku pada 
penelitian ini dengan teknik emotion regulation (seperti penelitian oleh Lotfali et al., 2016). Hal ini dapat dilakukan dengan teknik multiple baseline

Kelima, perilaku agresi verbal tidak sepenuhnya hilang pada kehidupan sehari-hari. $\mathrm{T}$ menunjukkan perilaku agresi verbal yang cukup tinggi saat ia marah kepada ibu pada dua kesempatan yang berbeda saat tahap intervensi. Ibu telah mencoba mengabaikannya, tetapi dirasa sulit karena besarnya volume suara $\mathrm{T}$ yang dikhawatirkan dapat mengganggu tetangga.

Kurangnya konsistensi perubahan dapat disebabkan oleh kurangnya kosistensi dari ibu dan nenek untuk menerapan program intervensi di luar sesi, sehingga perubahan yang terjadi selama intervensi tidak bertahan sepenuhnya dalam keseharian T. Salah satu faktor yang berperan dalam peningkatan perubahan perilaku anak dalam intervensi adalah adanya keterlibatan orangtua yang juga aktif dan konsisten menjalankan intervensi (Haine-schlagel \& Walsh, 2015). Kurangnya konsistensi ibu dalam menerapkan program intervensi aslah satunya adalah oleh kegagalan peneralan teknik opereant extinction dan MEO, yaitu memberikan pulsa kepada $\mathrm{T}$ pada pertengahan tahap intervensi (setelah sesi keempat) karena $\mathrm{T}$ meminta pulsa secara agresif kepada ibu dan nenek. Sikap ibu tersebut mengurangi efektifitas program intervensi karena perilaku agresi verbal tetap mendapatkan reinforcement, sementara itu seharusnya pada penerapan DRI reinforcement yang sebelumnya mempertahankan target perilaku harus dihilangkan atau paling tidak lebih sedikit dari pemberian reinforcement pada incompatible behavior (Miltenberger, 2012). Selain itu, pemberian pulsa juga memengaruhi efektifitas pulsa sebagai backup reinforcement, sehingga $\mathrm{T}$ kurang terlihat bersemangat saat peneliti mengingatkan pulsa sebagai reinforcement yang akan ia dapatkan. T kemudian tidak mampu memenuhi target token yang harus dimiliki untuk ditukarkan dengan backup reinforcement pada sesi ke 16, akan tetapi T tidak terlihat kecewa ataupun kesal. Meski demikian, pada tahap post test dan follow up, ibu menyatakan bahwa $\mathrm{T}$ tidak menujukkan perilaku agresi verbal selama 2 minggu setelah intervensi selesai dilakukan.

\section{SIMPULAN}

Penerapan teknik differentiated reinforcement of incompatible behavior (DRI) efektif untuk menurunkan perilaku agresi verbal pada remaja dengan gangguan moderate intellectual disability. Hal ini terlihat dari adanya penurunan hingga perilaku agresi verbal hilang (frekuensi sama dengan 0) dalam kurun waktu 30 menit setelah menjalani program intervensi, menurun dari yang selumnya sebanyak 4 kali dalam kurun waktu yang sama. Penurunan tersebut konsisten bertahan pada tahap follow up yang dilakukan 2 minggu setelah intervensi berakhir. Hal sejalan juga ditunjukkan oleh data kualitatif perilaku agresi verbal lebih banyak digunakan sebagai ekspresi kekesalan dan tidak serta merta bertujuan untuk menghina atau menyakiti seseorang. Di samping itu, adanya penerapan teknik relaksasi mampu meningkatkan kemampuan regulasi anak.

Hasil penelitian menunjukkan penerapan teknik differential reinforcement of incompatible behavior (DRI) efektif menurunkan perilaku agresi verbal pada anak dengan moderate intellectual disability. Maka, program intervensi serupa dapat diterapkan oleh orangtua, guru, dan terapis pada anak dengan moderate intellectual disability yang memiliki masalah perilaku agresi. Akan tetapi, penerapan program serupa lebih baik jika mengintegrasikan pelatihan regulasi emosi kepada anak, melibatkan pengasuh atau individu yang sering menjadi subjek agresifitas, dan diterapkan dalam beberapa situasi (rumah \& sekolah). Dengan demikian, perilaku agresi verbal anak menurun dan memiliki regulasi emosi yang lebih baik pada setiap situasi.

\section{DAFTAR PUSTAKA}

Ageranioti-Belanger, S., Brunet, S., D’Anjou, G., Tellier, G., Boivin, J., \& Gauthier, M. (2012). Behaviour disorders in children with an intellectual disability. Paediatrics and Child Health, 17(2), 84-88. Retrieved from http://www.pulsus.com/journals/pdf_frameset.jsp?j nlKy=5\&atlKy=10432\&isArt=t\&jnlAdvert=Paeds \&adverifHCTp=_NP\&sTitle=Behaviourdisordersi nchildrenwithanintellectualdisability,PulsusGroupI nc\&HCtype $=$ Consumer\%5Cnhttp://ovidsp.ovid.co m/ovidweb.cgi?T=JS\&PAGE=refe

Ahsan, M. (2015). Physical , Verbal , Anger and Hostility Aggressiveness in University' s Physical Education Students. International Journal of Sport and Physical Education (IJSPE), 1(2), 20-23.

Algahtani, F. (2017). Teaching students with intellectual disabilities: Constructivism or behaviorism? Educational Research and Reviews, 12(21), 10311035. https://doi.org/10.5897/ERR2017.3366

Association American Psychiatric. (2013). Diagnostic and Statistical Manual of Mental Disorders. Arlington, VA: American Psychiatric Publishing.

Babore, A., Carlucci, L., Cataldi, F., Phares, V., \& Trumello, C. (2017). Aggressive behaviour in adolescence: Links with self-esteem and parental emotional availability. Social Development, (January 2016), 1-13. https://doi.org/10.1111/sode.12236

Chowdhury, M., \& Benson, B. A. (2011). Research in Developmental Disabilities Review article Use of differential reinforcement to reduce behavior problems in adults with intellectual disabilities : A methodological review. Research in Developmental Disabilities, 32, 383-394 https://doi.org/10.1016/j.ridd.2010.11.015

Elmasry, N. M., Fouad, A. A., Khalil, D. M., \& Sherra, K. S. (2016). Physical and verbal aggression among adolescent school students in Sharkia, Egypt: 
prevalence and risk factors. Egyptian Journal of Psychology, $166-173$. https://doi.org/10.4103/1110-1105.195547

Gravetter, F. J., \& Forzano, L. B. (2012). Research Methods for The Behavioral Science (4th ed.). Belmont, CA: Cengage Learning.

Haine-schlagel, R., \& Walsh, N. E. (2015). A Review of Parent Participation Engagement in Child and Family Mental Health Treatment. Clinical Child Family Pshychology Review. https://doi.org/10.1007/s10567-015-0182-x

Hamilton, M. A. (2014). Verbal Aggression: Understanding The Psychological Antecedents and Social Consequences. Journal of Language and Social Social Consequences, 3(1), 5-12. https://doi.org/10.1177/0261927X11425032

Katz, G., Katz, G., \& Lazcano-ponce, E. (2008). Intellectual disability: definition, etiological factors, classification, diagnosis , treatment and prognosis, 50 .

Kratochwill, T. R., Hitchcock, J., Horner, R. H., Levin, J. R., Odom, S. L., Rindskopf, D. M., \& Shadish, W. R. (2010). Single-Case Design Technical Documentation. https://doi.org/10.4135/9781412957403.n457

Lotfali, S., Moradi, A., \& Ekhtiari, H. (2016). On the Effectiveness of Emotion Regulation Training in Anger Management and Emotional Regulation Difficulties in Adolescents. Modern Applied Science, $\quad 11(1), \quad 114$. https://doi.org/10.5539/mas.v11n1p114

Martin, G., \& Pear, M. (2013). Behavior Modification: What it is and How to do it (Tenth Edit). New Jersey: Pearson.

Marotz, L. R., \& Allen, K. E. (2013). Developmental Profiles: Pre-Birth Through Adolescence (7th ed.). Belmont: Wadsworth Cengage Learning.

Matson, J. L., Dixon, D. R., \& Matson, M. L. (2005). Assessing and treating aggression in children and adolescents with developmental disabilities: A 20year overview. Educational Psychology (Vol. 25). https://doi.org/10.1080/0144341042000301148

Miltenberger, R. G. (2012). Behavior Modification: Principles and Procedures. Wadsworth Cengage Learning (Fifth). California: Wadsworth Cengage Learning.

Pereira, C., \& Faria, S. (2013). Emotional development in children with intellectual disability-a comparative approach with "normal" children. Journal of Modern Education Review, 3(2), 120-136.

Rey Peña, L., \& Extremera Pacheco, N. (2012). PhysicalVerbal Aggression and Depression in Adolescents: The Role of Cognitive Emotion Regulation Strategies\rAgresión físico-verbal y depresión en adolescentes: el papel de las estrategias cognitivas de regulación emocional. Universitas Psychologica, 1245-1254. http://www.scielo.org.co/scielo.php?script=sci_artt ext\&pid=S1657-92672012000400018\&lang=pt

Spira, A. P., Koven, L. P., \& Edelstein, B. A. (2004). Using a Differential Reinforcement of Incompatible Behavior (DRI) Schedule to Reduce Maladaptive Behaviors. Clinical Case Studies, 3(2), 165-170. https://doi.org/10.1177/1534650103259624

Wardany, O. F., \& Choiri, A. S. (2017). The Effectiveness of Differential Reinforcement of Incompatible Behaviour (DRI) to Overcome Disruptive Behaviour of Intellectual Disability Students. European Journal of Special Eduation Research, 2(1), 23-37. https://doi.org/10.5281/zenodo.219585 